\title{
Internal sclerostomy using laser ablation of dyed sclera in glaucoma patients: a pilot study
}

Shlomo Melamed, Arieh Solomon, Doron Neumann, Ami Hirsh, Michael Blumenthal, Michael Belkin

\begin{abstract}
Twelve eyes of 12 patients with refractory glaucoma were treated with internal sclerostomy using laser ablation of dyed sclera. The technique involves iontophoretic impregnation of the sclera at the limbal region with $1 \%$ methylene blue and subsequent delivery of a pulsed dye laser beam to the stained area through a goniolens. The red wavelength of $664 \mathrm{~nm}$ generated by the laser is maximally absorbed by the stained sclera and creates a through and through sclerostomy. Successful complete sclerostomy was achieved in seven eyes $(58.3 \%)$ but there was some reduction of intraocular pressure (IOP) in all cases. Mean prelaser IOP (of all 12 eyes) was $36.6 \mathrm{~mm} \mathrm{Hg}$ and 1 hour after therapy it was reduced to 20.0 $\mathrm{mm} \mathrm{Hg}$. At the end of the follow-up period (mean 16 months) the mean IOP was $23.7 \mathrm{~mm}$ Hg; five eyes (41\%) maintained their IOP below $22 \mathrm{~mm} \mathrm{Hg}$, and the average number of medications per eye came down from 3.25 to 2.25 per eye. Transient corneal burns with Descemet's membrane folds adjacent to the laser impact zone were detected in eight eyes (67\%). No major complications like IOP spike, hyphaema, iridodialysis, or retinal detachment have been detected. Clear cornea and dark blue scleral staining are essential for the mechanical success of this procedure. Gonioscopic laser internal sclerostomy of methylene blue dyed sclera is technically feasible and the preliminary results of IOP control in refractory glaucoma are promising. Modifications of the iontophoresis process and laser parameters are currently under investigation in order to improve these results.
\end{abstract}

(Brf Ophthalmol 1993; 77: 139-144)

Conjunctival injury following surgical manipulation is believed to be the main reason for subconjunctival fibrosis and subsequent bleb failure in filtering surgery.' Complications of filtering surgery such as shallowing of the anterior chamber, hypotony, bleb leak and infection may also be related to conjunctival dissection and ocular penetration. In an attempt to avoid subconjunctival scarring, 5-fluorouracil ${ }^{2}$ or drainage setons ${ }^{3}$ have been used in refractory glaucoma. However, despite their relatively high success, both still involve invasive intraocular surgery.

Internal, minimally invasive sclerostomy with no conjunctival dissection would appear to offer advantages. Scheie was the first to describe the procedure termed goniopuncture, using a sharp blade to make a passage from the anterior chamber to the subconjunctival space. ${ }^{+}$Success- ful sclerostomies have already been reported using a mechanical drill, ${ }^{5}$ a laser beam delivered intracamerally through a fibreoptic probe, ${ }^{6-11}$ and Nd-YAG laser beam delivery through a goniolens. ${ }^{12-14}$ However, as the sclera has low optical absorption in the visible and near infrared portions of the spectrum, its ablation by lasers emitting in this region requires extremely high energy with subsequent damage to surrounding tissues. In an attempt to minimise energy levels, Latina et $a l^{15}$ developed the 'dyeenhanced sclerostomy' and successfully performed through and through sclerostomies in animals. ${ }^{15} 16$ The technique involves iontophoresis of the anterior sclera with methylene blue followed by its ablation using the flashlight pumped pulsed dye laser. The laser beam has a wavelength of $664 \mathrm{~nm}$ which is at the peak of the absorption curve of the stained sclera. Thus, the laser energy is maximally absorbed at the sclera, causing minimal damage to neighbouring tissues. Other methods of enhancement of scleral light absorption with fluorescein ${ }^{17}$ and silver oxide $^{18}$ were reported.

In the study presented here, gonioscopic laser internal sclerostomy of dye-enhanced sclera is described in 12 patients with refractory glaucoma.

\section{Materials and methods}

SELECTION OF PATIENTS

The criteria for inclusion of patients in the study were as follows:

(1) Age over 20 years.

(2) Visual acuity of counting fingers from 1 foot or less in the operated eye.

(3) Intraocular pressure (IOP) more than 26 $\mathrm{mm} \mathrm{Hg}$ in two consecutive measurements, despite maximally tolerated medical treatment.

(4) Patient's willingness to participate in the study and adherence to the follow-up schedule.

(5) Patient's signature on an informed consent after the potential risks and benefits of the procedure have been fully explained.

Patients with active neovascular glaucoma or corneal opacity preventing visualisation of the angle were not included in the study. However, patients with corneal oedema or bullous keratopathy were topical application of glycerin improved the view of the anterior chamber, as well as one patient with mild rubeosis of the iris but no detectable neovascularisation of the angle, were included.

Before laser treatment and at all intervals postoperatively all patients had a full ophthalmic examination which included: best corrected visual acuity, IOP measurement by applanation
Goldschleger Eye Institute, Chaim Shiba Medical Center, Tel-Hashomer 52621, Israel. Accepted for publication 21 October 1992 
tonometry, slit-lamp examination, and ophthalmoscopy.

Figures 1-3 Schematic illustration of the three steps of gonioscopic laser internal sclerostomy.

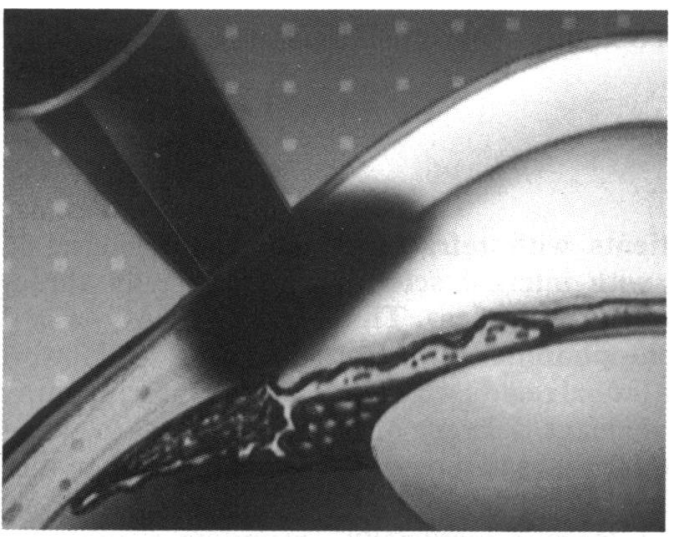

Figure 1 Iontophoresis of sclera with $1 \%$ solution of methylene blue through the conjunctiva.

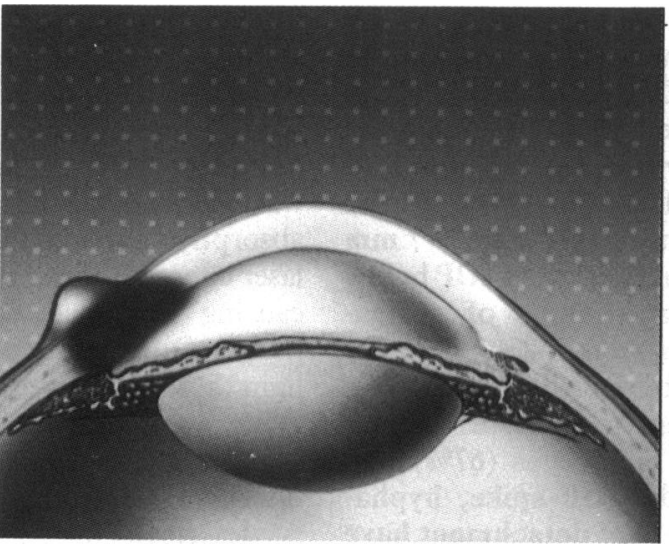

Figure 2 Elevation of conjunctiva from sclera using subconjunctival injection of balanced salt solution or sodium hyaluronate at the treatment site.

\section{OPERATIVE TECHNIQUE}

The site to be operated on was selected, the existence of a patent iridectomy and good conjunctival mobility being thought favourable.

Following retrobulbar anaesthesia, while the patient was in the supine position, topical drops of proparacaine hydrochloride $0.5 \%$ were instilled. A lid speculum was then inserted and an alligator clip connected to the negative pole of the iontophoresis power supply was attached to it. The positive pole was connected to a wire running through a glass pipette, previously filled with sterile $1 \%$ methylene blue solution in distilled water. The pipettes were prepared with tip openings of $100-150 \mu \mathrm{m}$, to minimise leakage and excessive corneal staining.

The duration of each iontophoresis staining was 5-7 minutes, using a current of $0 \cdot 2-0 \cdot 4 \mathrm{~mA}$. At the selected operation site, the sclera was focally dyed at the limbus and then $2-3 \mathrm{~mm}$ posterior to limbus by iontophoretically applying methylene blue through the conjunctiva, to

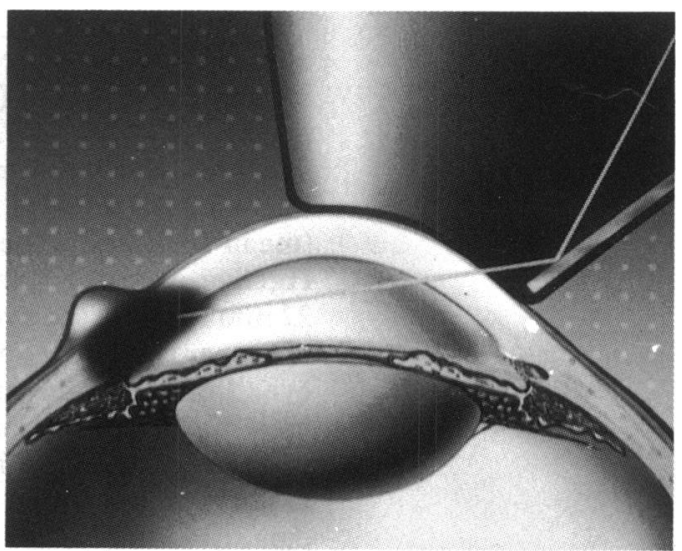

Figure 3 Delivery of laser beam ( $664 \mathrm{~nm}$ ) through the gonioscopic lens to the methylene blue stained sclera.

Table 1 Internal laser sclerostomy-patients' data

\begin{tabular}{|c|c|c|c|c|c|c|c|}
\hline $\begin{array}{l}\text { Patient } \\
\text { no }\end{array}$ & $\begin{array}{l}\text { Age } \\
\text { (years) }\end{array}$ & Sex & Diagnosis & Preceding operations & Visual acuity & $\begin{array}{l}\text { Intraocular } \\
\text { pressure } \\
(\mathrm{mm} \mathrm{Hg})\end{array}$ & Medical $R x$ \\
\hline 1 & 80 & $\mathbf{M}$ & $\begin{array}{l}\text { Primary open angle } \\
\text { glaucoma, corneal oedema }\end{array}$ & - & $\begin{array}{l}\text { No light } \\
\text { perception }\end{array}$ & 47 & $\begin{array}{l}\text { Timolol, pilocarpine, } \\
2 \% \text { propine, diamox }\end{array}$ \\
\hline 2 & 77 & $\mathbf{M}$ & $\begin{array}{l}\text { Traumatic glaucoma, mature } \\
\text { cataract }\end{array}$ & 1 filter & $\begin{array}{l}\text { No light } \\
\text { perception }\end{array}$ & 50 & $\begin{array}{l}\text { Timolol, pilocarpine } \\
2 \% \text {, diamox }\end{array}$ \\
\hline 3 & 55 & $\mathbf{M}$ & $\begin{array}{l}\text { Primary open angle } \\
\text { glaucoma, old retinal } \\
\text { detachment }\end{array}$ & - & $\begin{array}{l}\text { No light } \\
\text { perception }\end{array}$ & 36 & $\begin{array}{l}\text { Timolol, propine, } \\
\text { diamox }\end{array}$ \\
\hline 4 & 65 & $\mathbf{F}$ & $\begin{array}{l}\text { Chronic closure angle } \\
\text { glaucoma, central retinal } \\
\text { vein occlusion, bullous } \\
\text { keratotomy }\end{array}$ & - & $\begin{array}{l}\text { No light } \\
\text { perception }\end{array}$ & 52 & Pilocarpine 2\%, diamox \\
\hline 5 & 38 & M & Pigmentary glaucoma & - & $\begin{array}{l}\text { Hand } \\
\text { movements }\end{array}$ & 27 & $\begin{array}{l}\text { Timolol, propine, } \\
\text { diamox }\end{array}$ \\
\hline 6 & 75 & M & $\begin{array}{l}\text { Chronic angle closure } \\
\text { glaucoma, corneal oedema }\end{array}$ & $\begin{array}{l}\text { Extracapsular cataract } \\
\text { extraction }+ \\
\text { intraocular lens } \\
\text { implantation }\end{array}$ & $\begin{array}{l}\text { No light } \\
\text { perception }\end{array}$ & 27 & $\begin{array}{l}\text { Timolol, propine, } \\
\text { pilocarpine 2\%, } \\
\text { diamox }\end{array}$ \\
\hline 7 & 80 & $\mathbf{F}$ & $\begin{array}{l}\text { Chronic angle closure } \\
\text { glaucoma, aphakia }\end{array}$ & 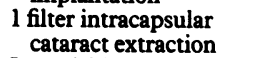 & $\begin{array}{l}\text { No light } \\
\text { perception }\end{array}$ & 38 & $\begin{array}{l}\text { Timolol, propine, } \\
\text { neptazane }\end{array}$ \\
\hline 8 & 72 & $\mathbf{M}$ & $\begin{array}{l}\text { Chronic angle closure } \\
\text { glaucoma, central retinal } \\
\text { vein occlusion }\end{array}$ & $\begin{array}{l}\text { Laser iridotomy } \\
\text { extracapsular } \\
\text { cararact extraction+ } \\
\text { intraocular lens } \\
\text { implantation }\end{array}$ & $\begin{array}{l}\text { Hand } \\
\text { movements }\end{array}$ & 36 & $\begin{array}{l}\text { Timolol, pilocarpine } \\
2 \%, \text { diamox }\end{array}$ \\
\hline 9 & 70 & $\mathbf{M}$ & Primary open angle glaucoma & Filter $\times 2$ & $\begin{array}{l}\text { Hand } \\
\text { movements }\end{array}$ & 28 & $\begin{array}{l}\text { Timolol, pilocarpine, } \\
2 \% \text { propine, diamox }\end{array}$ \\
\hline 10 & 69 & $\mathbf{M}$ & Traumatic glaucoma & 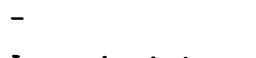 & $\begin{array}{l}\text { No light } \\
\text { perception }\end{array}$ & 30 & \\
\hline 11 & 75 & $\mathbf{F}$ & $\begin{array}{l}\text { Chronic angle closure } \\
\text { glaucoma, retinitis } \\
\text { pigmentosa, corneal } \\
\text { oedema }\end{array}$ & $\begin{array}{l}\text { Laser trabeculoplasty } \\
\text { extracapsular } \\
\text { cataract extraction+ } \\
\text { intraocular lens } \\
\text { implantation }\end{array}$ & $\begin{array}{l}\text { Hand } \\
\text { movements }\end{array}$ & 32 & $\begin{array}{l}\text { Timolol, pilocarpine } \\
2 \% \text {, diamox }\end{array}$ \\
\hline 12 & 65 & $\mathbf{M}$ & Primary open angle glaucoma & - & $\begin{array}{l}\text { No light } \\
\text { perception }\end{array}$ & 36 & $\begin{array}{l}\text { Timolol, pilocarpine } \\
2 \%, \text { propine, } \\
\text { neptazane }\end{array}$ \\
\hline
\end{tabular}


ensure good dye absorption of the sclera along the anticipated oblique route of the laser sclerostomy, thus staining both the internal and the external portions of the expected sclerostomy route.

A single mirror gonioscopic lens, the CGF lens, ${ }^{14}$ was used to confirm the presence of dye in the angle, anterior to Schwalbe's line.

In order to prevent inadvertent perforation of the conjunctiva, the stained conjunctiva was elevated with an injection of balanced salt solution using a $\mathbf{3 0}$ gauge needle inserted at a site adjacent to the planned filtration bleb. In two patients, subconjunctival injection of sodium hyaluronate was performed.

The laser used was the flashlight pumped pulsed dye laser (Candela Laser Corporation, Wayland, MA). This laser delivers pulses of high energy (100-400 mJ per pulse) with pulse duration of $10 \mu \mathrm{s}$ and spot size of $200 \mu \mathrm{m}$. The laser emits red light (664 $\mathrm{nm}$ wavelength) which is maximally absorbed by the methylene blue. The laser light was coupled to the slit-lamp delivery system using a $200 \mu \mathrm{m}$ fibre. The beam was directed into the angle through the CGF goniolens. ${ }^{19}$

The basic steps of the procedure are schematically illustrated in Figures 1-3.

\section{POSTOPERATIVE FOLLOW UP}

Patients were prescribed prednisolone acetate $1 \%$ drops four times daily initially; tapering off to nil after 1 month. In addition, all antiglaucoma medications were discontinued immediately after treatment. The decision to restart treatment was based on postoperative IOP measurements.

Starting 1 hour after treatment, IOP measurement and slit-lamp examinations were performed hourly for 3 hours. The following day, 1 week, 1 month, 3, and 6 months after treatment, visual acuity and IOP were measured, and slit-lamp examination and ophthalmoscopy were performed. All major as well as minor complications of the procedure were documented and, when required, treated medically.

The study was conducted under an Investigational Device Exemption of the Food and Drug Administration (IDE number G880001) and approved by the Israeli Ministry of Health and the institutional human use review board (Helsinki Committee).

\section{Results}

Twelve eyes of 12 patients were treated in this

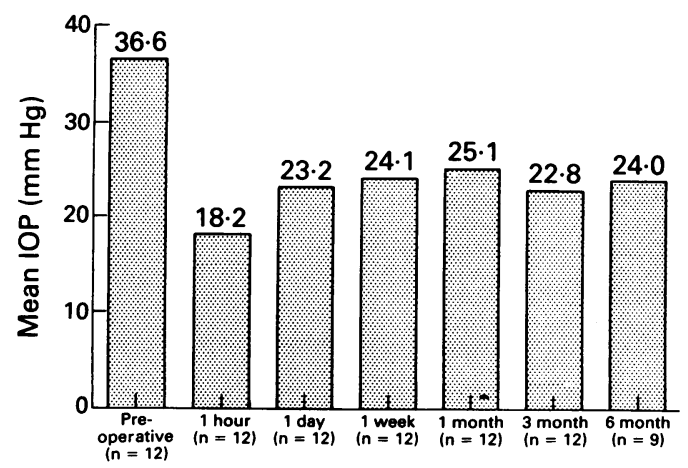

Figures 5-7 A representative case of successful gonioscopic laser internal sclerostomy.

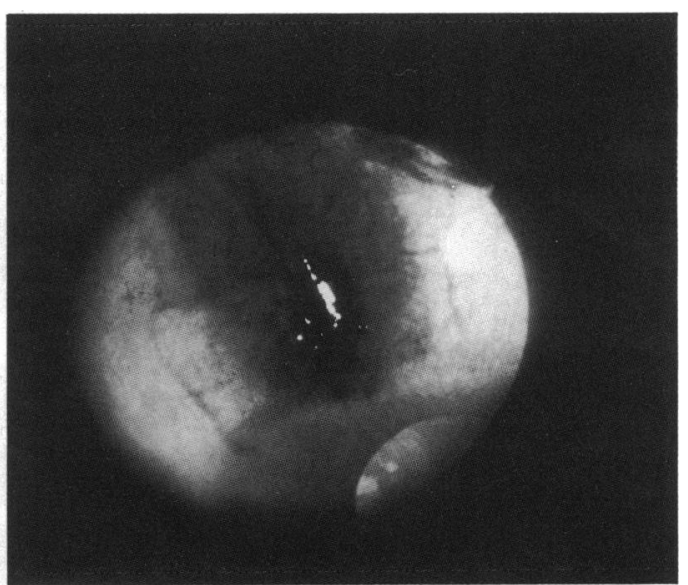

Figure 5 Immediately following iontophoresis of 1\% methylene blue - conjunctival staining.

study. There were nine men and three women with a mean age of 68.4 years (ranging from 38 to 80 years). Mean follow-up time was 16 months (ranging from 13 to 20 months). All patients had end-stage glaucoma as a result of various conditions: primary open angle glaucoma (four eyes), chronic angle closure glaucoma (five eyes), post traumatic glaucoma (two eyes) and pigmentary glaucoma (one eye). Associated ocular diagnoses included: corneal oedema or bullous keratopathy (four eyes), central retinal vein occlusion (two eyes), old retinal detachment (one eye), and retinitis pigmentosa (one eye). Six eyes had at least one previous intraocular operation. Three eyes had at least one filtering surgery and four eyes had previous cataract surgery (three with and one without intraocular lens implantation). The average number of antiglaucoma medications per eye was $3 \cdot 25$ (Table 1 ).

The end-point of the procedure was very hard to evaluate. The main indication for a successful sclerostomy was the immediate, sharp reduction of IOP. In several eyes, accompanying signs of a through and through opening were evident, such as subconjunctival gas bubbles, subconjunctival haemorrhage, turbulence of debris in the anterior chamber, and diffuse elevation of a conjunctival bleb.

The mean preoperative IOP was $36.6 \mathrm{~mm} \mathrm{Hg}$

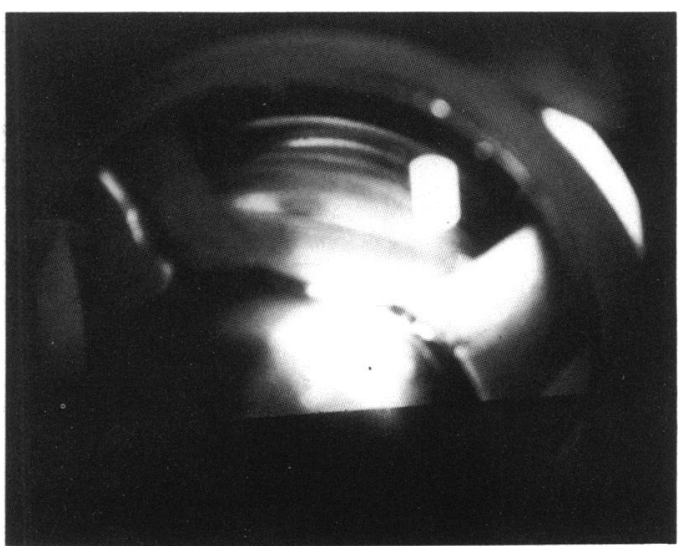

Figure 6 Immediately following iontophoresis of $1 \%$ methylene blue. A gonioscopic view of the treatment site showing dense blue $(+++)$ scleral staining anterior to
Schwalbe's line.
Figure 4 Response of mean intraocular pressure to sclerostomy. 
Figure 7 Successful sclerostomy 5 months following gonioscopic view of lased site displays blanching and elevation of Descemet's membrane. Note retrodisplacement of the iris posterior to sclerostomy site. Intraocular pressure $=11 \mathrm{~mm}$ Hg.

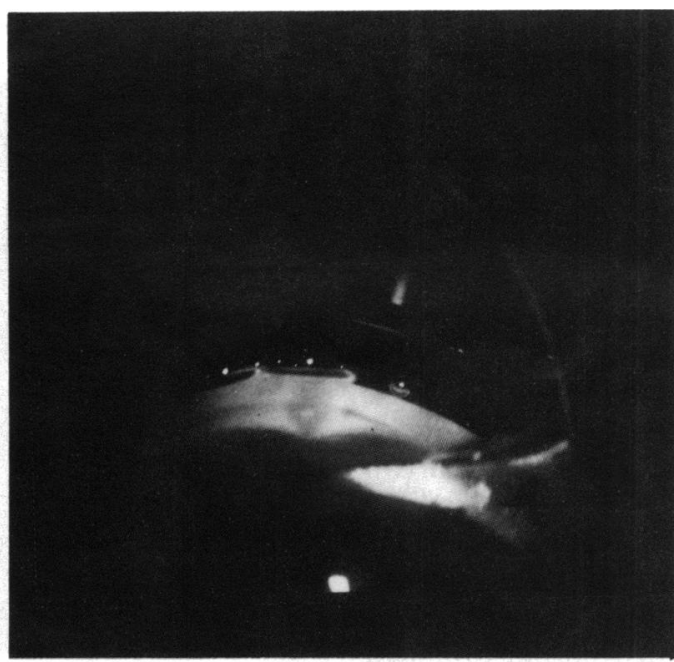

(range: 27 to $52 \mathrm{~mm} \mathrm{Hg}$ ). The mean IOP 1 hour after laser treatment was $20.0 \mathrm{~mm} \mathrm{Hg}$ (range: 2 to $44 \mathrm{~mm} \mathrm{Hg}$ ). At the end of the follow-up period, mean IOP was $24.5 \mathrm{~mm} \mathrm{Hg}$ (ranging from 11 to $38 \mathrm{~mm} \mathrm{Hg}$ ). Figure 4 depicts the response of mean IOP of the operated eyes over time.

In seven eyes $(58.3 \%)$ a patent through and through sclerostomy was evident immediately post laser treatment. This was associated with marked reduction of IOP in all cases. In two eyes, gas bubbles were detected under the conjunctiva above the operated site. These bubbles were first detected immediately after the laser application, remained visible for 3-4 hours afterwards and disappeared within 24 hours. The average laser energy required to complete a sclerostomy was $3.575 \mathrm{~J}$ (13 shots of $275 \mathrm{~mJ}$ each). Subconjunctival haemorrhage after laser treatment occurred in four eyes, and it usually resolved within 2 weeks. Evaluated 1 week after treatment only one eye displayed a high filtration bleb while in four eyes the filtration bleb was very low and diffuse and in two eyes the bleb could not be demonstrated at all despite substantial reduction of IOP. There was shallowing of the anterior chamber in one eye only, the same eye that had a very high filtration bleb (patient no 11). Long term, none of these seven eyes had a detectable filtration bleb.

Gonioscopically, blanching of the stained sclera was noted in all cases. The Descemet's membrane was successfully perforated in 11 of 12 eyes $(91 \cdot 6 \%)$. In most cases, the Descemet's membrane was found to be elevated and open with cracks and tears of variable sizes and shapes. In some cases, a large flap of Descemet's membrane was formed, with its free edge elevated and exposing the internal sclerostomy. Retrodisplacement of the iris was detected in two eyes $(16 \cdot 6 \%)$.

Three degrees of methylene blue staining were achieved:,,++++++ . Dark blue stain $(+++)$ was observed in five eyes and in all of them the sclerostomy was associated with marked reduction of IOP. Conversely, all three eyes with light blue staining of the sclera (defined as $(+)$ only) had partial sclerostomies. In four eyes with moderate stain $(++)$, only two had reduced IOP. In two eyes, both with scarred and congested conjunctiva, quick turnover of the methylene blue within 30 minutes required repeated iontophoresis before laser treatment.

Figures 5, 6, and 7 display a representative successful internal laser sclerostomy of dye enhanced sclera.

\section{COMPLICATIONS}

Flare and cells could be detected in all eyes immediately after the procedure. It resolved within 1 week.

Localised corneal oedema with Descemet's membrane folds were detected in eight eyes (67\%). These findings usually resolved within 1-7 days. In one eye, localised Descemet's membrane tear was noted in the corneal periphery adjacent to the sclerostomy site, and was present for 3 months.

One eye that had bullous keratopathy before laser treatment developed persistent corneal erosion and subsequent inflammatory infiltrate that cleared after antibiotic therapy.

Only one eye displayed minimal bleeding in the angle at the treatment site immediately after laser treatment (patient no 1). There was no frank hyphaema and no immediate IOP elevation, retinal detachment, or choroidal effusion after treatment in any eye.

All data regarding treatment parameters, immediate and long term response are summarised in Tables 2 and 3. The response of IOP in all 12 patients is graphically displayed in Figure 8.

\section{Discussion}

Our preliminary results with gonioscopic laser

Table 2 Intermal laser sclerostomy-treatment parameters and immediate response

\begin{tabular}{|c|c|c|c|c|c|c|c|}
\hline $\begin{array}{l}\text { Pationt } \\
\text { no }\end{array}$ & $\begin{array}{l}\text { Intraocular } \\
\text { pressure } \\
\text { (prelaser) }\end{array}$ & $\begin{array}{l}\text { Methylene } \\
\text { blue } \\
\text { staining }\end{array}$ & $\begin{array}{l}\text { Laser energy } \\
\text { ( } \mathrm{m} \text { per pulse } \\
\times \text { no of pulses) }\end{array}$ & Sclerostomy & $\begin{array}{l}\text { Intraocular } \\
\text { pressure } \\
\text { (postlaser) }\end{array}$ & $\begin{array}{l}\text { Presence } \\
\text { of bleb }\end{array}$ & Remarks \\
\hline 1 & 47 & ++ & $250 \times 11$ & Partial & 44 & - & $\begin{array}{l}\text { Poor view, corneal oedema blood in Rx site, } \\
\text { Descemet's folds }\end{array}$ \\
\hline $\begin{array}{r}2 \\
3 \\
4 \\
5 \\
6 \\
7 \\
8 \\
9 \\
10 \\
11\end{array}$ & $\begin{array}{l}50 \\
36 \\
52 \\
27 \\
27 \\
38 \\
36 \\
28 \\
30 \\
32\end{array}$ & $\begin{array}{l}+ \\
++ \\
+ \\
+++ \\
++ \\
+++ \\
+++ \\
+++ \\
+ \\
++\end{array}$ & $\begin{array}{l}220 \times 16 \\
250 \times 12 \\
250 \times 5 \\
250 \times 17 \\
310 \times 30 \\
300 \times 12 \\
280 \times 10 \\
250 \times 7 \\
310 \times 12 \\
330 \times 10\end{array}$ & $\begin{array}{l}\text { Partial } \\
\text { Complete } \\
\text { Partial } \\
\text { Complete } \\
\text { Partial } \\
\text { Complete } \\
\text { Complete } \\
\text { Complete } \\
\text { Partial } \\
\text { Complete }\end{array}$ & $\begin{array}{r}34 \\
12 \\
36 \\
14 \\
18 \\
18 \\
18 \\
12 \\
22 \\
2\end{array}$ & $\begin{array}{l}\overline{+} \\
\overline{+} \\
+ \\
\bar{t} \\
\bar{t} \\
\overline{t+}\end{array}$ & $\begin{array}{l}\text { Poor view, Descemet's folds } \\
\text { Gas bubbles under bleb corneal burn } \\
\text { Poor view, bullous keratopathy } \\
\text { Subconjunctival haemorrhage } \\
\text { Poor view, corneal oedema } \\
\text { Descemet's tear } \\
\text { Corneal burn subconjunctival haemorrhage } \\
\text { Subconjunctival haemorrhage corneal burn } \\
\text { Descemet's folds } \\
\text { Gas bubbles, high bleb, shallow anterior }\end{array}$ \\
\hline 12 & 36 & +++ & $300 \times 16$ & Complete & 18 & ++ & Subconjunctival haemorrhage \\
\hline
\end{tabular}

-Bleb was evaluated I week after laser internal sclerostomy. 
Table 3 Internal laser sclerostomy - long term results

\begin{tabular}{|c|c|c|c|c|c|}
\hline $\begin{array}{l}\text { Patient } \\
\text { no }\end{array}$ & $\begin{array}{l}\text { Follow-up } \\
\text { time } \\
\text { (months) }\end{array}$ & $\begin{array}{l}\text { Intraocular } \\
\text { pressure }\end{array}$ & Medical Rx & Sclerostomy & Remarks \\
\hline 1 & 20 & 38 & $\begin{array}{l}\text { Timolol, pilocarpine } 2 \% \text {, } \\
\text { propine, diamox }\end{array}$ & Closed &. \\
\hline 2 & 20 & 29 & $\begin{array}{l}\text { Timolol, pilocarpine } 2 \%, \\
\text { neptazane }\end{array}$ & Closed & - \\
\hline $\begin{array}{l}3 \\
4\end{array}$ & $\begin{array}{l}18 \\
16\end{array}$ & $\begin{array}{l}11 \\
34\end{array}$ & $\begin{array}{l}\text { Diamox } \\
\text { Timolol, diamox }\end{array}$ & $\begin{array}{l}\text { Open } \\
\text { Closed }\end{array}$ & $\begin{array}{l}\text { Corneal abscess } \\
\text { resolved with } \\
\text { medical Rx }\end{array}$ \\
\hline 5 & 16 & 13 & - & $\begin{array}{l}\text { Closed } \\
\text { cyclodialysis? }\end{array}$ & - \\
\hline 6 & 16 & 25 & $\begin{array}{l}\text { Timolol, pilocarpine } 2 \% \text {, } \\
\text { propine, diamox }\end{array}$ & Closed & - \\
\hline 7 & 16 & 19 & $\begin{array}{l}\text { Timolol, propine, } \\
\text { neptazane }\end{array}$ & $\begin{array}{l}\text { Open, but tissue } \\
\text { fills in }\end{array}$ & Descemet's roll \\
\hline $\begin{array}{l}8 \\
9\end{array}$ & $\begin{array}{l}16 \\
16\end{array}$ & $\begin{array}{l}22 \\
24\end{array}$ & Timolol, pilocarpine $2 \%$ & $\begin{array}{l}\text { Open } \\
\text { Closed }\end{array}$ & $\overline{-}$ \\
\hline 10 & 13 & 21 & $\begin{array}{l}\text { Timolol, propine, } \\
\text { pilocarpine } 2 \% \text {, diamox }\end{array}$ & $\begin{array}{l}\text { Open } \\
\text { cyclodialysis? }\end{array}$ & - \\
\hline $\begin{array}{l}11 \\
12\end{array}$ & $\begin{array}{l}13 \\
13\end{array}$ & $\begin{array}{l}26 \\
33\end{array}$ & $\begin{array}{l}\text { Tímolol, diamox } \\
\text { Timolol, neptazane }\end{array}$ & $\begin{array}{l}\text { Closed } \\
\text { Closed }\end{array}$ & $\overline{-}$ \\
\hline
\end{tabular}

Figure 8 Intraocular pressure response to laser sclerostomy in 12 patients.

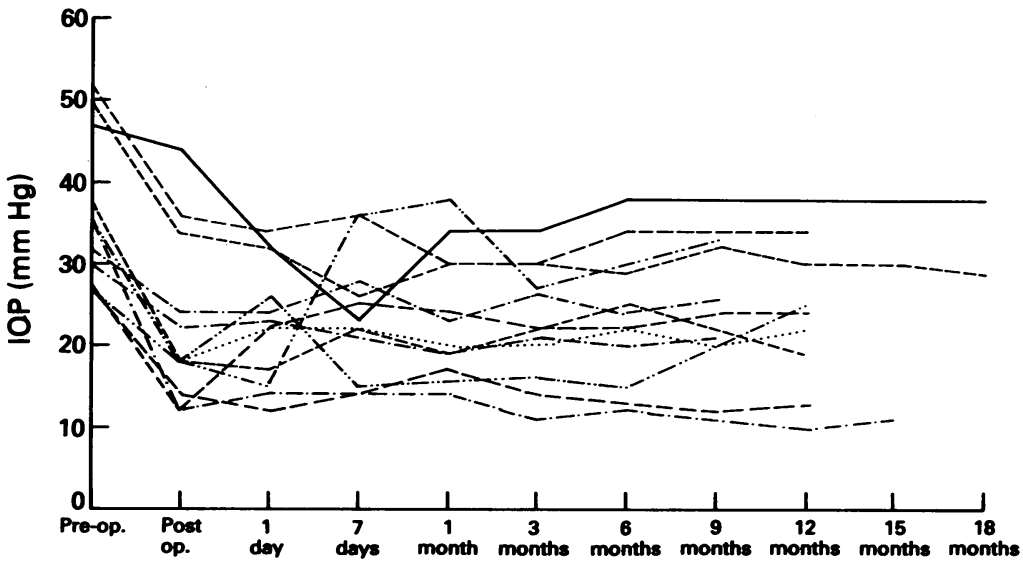

important role in the success of the laser sclerostomy.

Clear cornea is essential for proper visualisation of the angle through the gonioscope and efficient laser delivery to the sclera. All four eyes that had pre-existing corneal oedema had only partial sclerostomy. Treatment in all eyes was more difficult owing to the relatively poor view, despite application of topical glycerin for 1 minute.

As expected, long term success rate of laser sclerostomy was affected by the extent of previous surgical manipulation. Four of the six eyes that did not have any surgical intervention before laser sclerostomy were successfully treated, maintaining low IOP with open sclerostomy several months after therapy. This is not surprising, as eyes with previous intraocular surgery usually do poorly after surgical filtering as well. ${ }^{20}$

Scarred conjunctiva apparently reduces conductivity of methylene blue and is less compliant to the subconjunctival injection. This may affect both the feasibility of sclerostomy formation and long term control of IOP.

One of the main problems remaining is the definition of the end point of the procedure. During treatment, only one eye demonstrated some turbulence of debris that could indicate perforation. In all other eyes, no obvious signs of through and through scleral opening (like anterior chamber shallowing) could be noted during laser treatment. However, as there were no major complications associated with additional laser shots, we believe that overtreatment may not present a special hazard to the eye. Treatment should be allowed to continue until subsequent shots no longer create scleral ablation (usually no more than 20 shots are sufficient).

Signs of successful sclerostomy were evaluated immediately post laser treatment and included: (1) a marked reduction in IOP, (2) detection of gas bubbles under the conjunctiva, suggesting direct communication between the anterior chamber and the subconjunctival space, (3) subconjunctival haemorrhage occurring after laser treatment, suggesting rupture of blood vessels either at the episcleral or conjunctival level. The occurrence of a conjunctival bleb was considered non-contributary at this stage, as most of the conjunctival elevation should be related to the preceding injection.

After sclerostomy, only one eye had a high filtration bleb with shallowing of the anterior chamber, while all other eyes had very diffuse and shallow bleb or no detectable bleb at all. Previously reported diameters of contact laser sclerostomies were in the range of 200-300 $\mu \mathrm{m} .{ }^{9}{ }^{\text {is }} \mathrm{We}$ believe the relatively small diameter of the laser sclerostomy compared with surgical sclerectomy may explain the different bleb appearance seen in our patients. Such sclerostomy may result in very slow percolation of aqueous out of the anterior chamber, with relatively low pressure head forming at the episclera and less conjunctival distension. Furthermore, during surgery, the subconjunctival space is swept mechanically with a blunt instrument, separating the conjunctiva from sclera and allowing more efficient bleb formation. We also 
presume that obliquity of the sclerostomy along with its uneven internal surfaces may add a valve-like mechanism which will control aqueous flow through. Also, as no iris incarceration was noted at the sclerostomy site, peripheral iridectomy may not be needed in this procedure.

As described for another laser treatment to the angle, the Nd-YAG laser trabeculopuncture, ${ }^{21} 22$ in some patients IOP was well controlled despite the absence of a detectable patent trabeculotomy.

Even when there was good long term control of IOP, no eye had a visible bleb. Possibly, one or more of several other mechanisms may be involved: (1) complete narrow sclerostomy allowing percolation of aqueous out but no conjunctival elevation; (2) partial sclerostomy communicating with collector channels or allowing direct diffusion of aqueous through a very thin layer of remnant tissue; (3) cyclodialysis effect with increased uveoscleral outflow; (4) reduced aqueous formation either through direct laser impact or subsequent uveitis; (5) a different conjunctival reaction from that seen in conventional fistulising surgery because the conjunctiva was not surgically dissected.

Despite delivery of very high laser energy, no major damage to adjacent tissues was noted. Eight eyes (67\%) displayed corneal oedema adjacent to laser impact zone, with some Descemet folds radiating from that region. This complication was transient and usually resolved within 1-2 weeks. There were no major complications such as increased IOP, hyphaema, retinal detachment, and corneal or conjunctival perforation.

In conclusion, gonioscopic laser internal sclerostomy of dye enhanced sclera is technically feasible. Even in end stage glaucoma patients, some eyes kept their IOP well controlled for several months. Modifications of the iontophoresis process and laser parameters are currently under investigation in an attempt to improve these preliminary results.
1 Skuta GL, Parrish RK II. Wound healing in glaucoma filtering surgery. Surv Ophthalmol 1987; 32: 149.

2 Heuer DK, Parrish RK II, Gressel MG, Hodapp E, Palmberg PF. 5-Fluorouracil and glaucoma filtering surgery. II. A pilot study. Ophthalmology 1984; 91: 384.

3 Minckler DS, Heuer DK, Hasty B, Baervelot G, Cutting AC, Barlon WE. Clinical experience with the single-plate Molteno implant in complicated glaucomas. Ophthalmology 1988; 95: 1181 .

4 Scheie HG. Goniopuncture - a new filtering operation for glaucoma: preliminary report. Arch Ophthalmol 1950; 44 761.

5 Brown RH, Lynch MG, Denham DB, Bruner WB, Parel JM, Palbberg $\mathrm{P}$, et al. Internal sclerectomy with an automated trephine for glaucoma. Ophthalmology 1988; 95: 728.

6 Jaffe GJ, Mieler WF, Radius RL. Ab-interno sclerostomy with a high powered argon endolaser. Arch Ophthalmol 1989; 107: 1183-5.

7 Berlin MS, Rajacich G, Duffy M, Grundfest W, Goldenberg T. Excimer laser photoablation in glaucoma filtering T. Excimer laser photoablation in g

8 Gaasterland DE, Hennings DR, Boutacoff TA, Bilek C. Ab interno and ab externo filtering operations by laser contact surgery. Ophthalmic Surg 1987; 18: 254.

9 Higginbotham EJ, Kao G, Peyman G. Internal sclerostomy with the Nd-YAG contact laser versus thermal sclerostomy in rabbits. Ophthalmology 1988; 95: 385.

10 Federman JL, Wilson RP, Ando F, Peyman GA. Contact laser thermal sclerostomy ab interno. Ophthalmic Surg 1987; 18: 726.

11 Jaffe GJ, Williams GA, Mieler WF, Radius RL. Ab interno sclerostomy with a high powered argon laser. $A m \mathcal{F}$ Ophthalmol 1988; 106: 391 .

12 March WF, Gherezghiher T, Koss MC, Nordquist RE. Experimental Yag laser sclerostomy. Arch Ophthalmol 1984; 102: 1834 .

13 March WF, Gherezghiher T, Koss MC, Shaver RP, Heath WD, Nordquist RD. Histologic study of Nd-YAG laser sclerostomy. Arch Ophthalmol 1985; 103: 860.

14 March WF, Lafuente H, Rol P. Improved goniolens for YAG sclerostomy. Ophthalmic Surg 1987; 18: 513.

15 Latina M, Goode S, DeKater AW, Long FH, Deutch TF, Epstein DL. Experimental ab interno sclerostomies using a pulsed-dye laser. Lasers Surg Med 1988; 8: 233.

16 Latina MA, Dobrogowski M, March WF, Birngruber R. Laser sclerostomy by pulsed dye laser and goniolens. Arch Ophthalmol 1990; 108: 1745 .

17 March WF, Shaver RP. Fluorescein in laser sclerostomy. Am fOphthalmol 1987; 104: 432.

18 March WF, Shaver RP, Gherezghiher T, Nordquist RE Silver oxide in YAG sclerostomy. Lasers Surg Med 1987; 7: 353.

19 March WF, Gherezghiher T, Koss MC, Nordquist RE. Design of new contact lens for YAG laser filtering procedures. Ophthalmic Surg 1985; 16: 328.

20 Heuer DK, Gressel MG, Parrish RK II, Anderson DR, Hodapp E, Palmberg PF. Trabeculectomy in aphakic eyes. Ophthalmology 1984;91: 1045.

21 Melamed S, Pei J, Epstein DL. Q switched Nd-YAG laser trabeculopuncture in monkeys. Arch Ophthalmol 1985; 103: 129.

22 Melamed S, Latina M, Epstein DL. Nd-YAG laser trabeculopuncture in juvenile glaucoma. Ophthalmology 1987; 96: 163. 